\title{
Incidental Cystic Encephalomalacia from a Silent Cerebral Infarct
}

\author{
Zanna Voysey MD ${ }^{1}$, Steve Connor $\mathrm{MD}^{2}$, Ananth Purinak $\mathrm{MD}^{3}$, Naheed Khan MD PhD ${ }^{1,4}$ \\ ${ }^{1}$ Department of Neurology, Kings College Hospital, Denmark Hill, London, UK \\ ${ }^{2}$ Department of Neuroradiology, Kings College Hospital, Denmark Hill, London, UK \\ ${ }^{3}$ Priority House, Kent and Medway NHS Partnership Trust, Maidstone, Kent, UK \\ ${ }^{4}$ Department of Neurology, Maidstone Hospital, Kent, UK
}

Submission: March 03, 2017; Published: June 19, 2017

*Corresponding author: Dr Naheed Khan, Department of Neurology, Kings College Hospital, Denmark Hill, and Maidstone Hospital, Kent, London, UK, Email: nkhan1@nhs.net

Text

An 86 year old lady presented with a two year history of progressive cognitive decline. The ACE-R identified global, memory-predominant cognitive impairment (51/100). There was a history of hypertension and hyperlipidaemia and no other medical history. An MRI brain confirmed hippocampal atrophy consistent with a diagnosis of Alzheimer's disease. It also revealed an additional striking finding of a multi-cystic abnormality in the left medial frontal lobe (Figure 1). The MRI brain was repeated and findings were unchanged one year later.

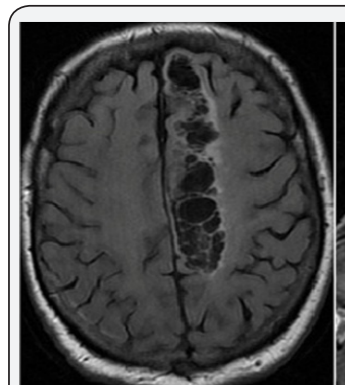

A

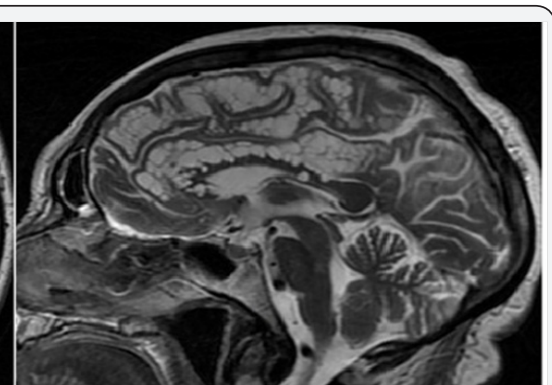

B
Figure 1: (A) Sagittal T2W; (B): Axial FLAIR images show signal change within the left medial frontal lobe extending to the cingulate gyrus and corpus callosum with CSF-iso intense spaces with additional T2/FLAIR high signal change.

Cystic encephalomalacia is a region of septated, cavitated signal change that follows an acquired parenchymal brain injury such as trauma, infection or ischaemia. The presence of cardiovascular risk factors along with the precise conformation of the lesion to a vascular territory (in this case, the left anterior cerebral artery) makes cystic encephalomalacia secondary to a 'silent' anterior cerebral artery infarct the most likely aetiology here. Giant perivascular spaces (PVS) or Virchow-Robin spaces, like cystic encephalomalacia exhibitiso-intensity, appear clustered and demonstrate relative sparing of the cortex as seen here. However PVS are benign expansions of normal pial-lined perivascular spaces [1] and so follow the course of more distal penetrating arteries. In addition they are typically found in the mesencephalothalamic regionbut can rarely occur in anterior superior temporal or even cingulate areas [2].

Porencephalic cysts are rare and characterized by communication with the ventricular system [3]. Neuroglial cysts are smooth, well demarcated lesions distinct from the multicystic structure described in our patient. A cystic neoplasm would not follow a precise vascular territory or demonstrate iso-intensity with CSF [3] and after a 12 month interval would be expected to progress both clinically and radiologically. The radiological findings were consistent with incidental cystic encephalomalacia from a silent cerebral infarct and hippocampal atrophy supporting the clinical features of Alzheimer's disease.

\section{References}

1. Salzman K, Osborn AG, House P, Jinkins JR, Ditchfield A, et al. (2005) Giant Tumefactive Perivascular spaces. Am J Neuroradiology 26(2): 298-305.

2. Rawal S, Croul SE, Willinsky RA, Tymianski M, Krings T (2014) Subcortical cystic lesions within the anterior superior temporal gyrus: a newly recognized characteristic location for dilated perivascular spaces. Am J Neuroradiology 35(2): 317-322.

3. Osborn AG, Preece MT (2006) Intracranial Cysts: Radiologic-Pathologic Correlation and Imaging Approach. Radiology 239(3): 650-654. 
CC (i) This work is licensed under Creative Commons Attribution 4.0 Licens

DOI: 10.19080/OAJNN.2017.04.555635

\section{Your next submission with Juniper Publishers} will reach you the below assets

- Quality Editorial service

- Swift Peer Review

- Reprints availability

- E-prints Service

- Manuscript Podcast for convenient understanding

- Global attainment for your research

- Manuscript accessibility in different formats ( Pdf, E-pub, Full Text, Audio)

- Unceasing customer service

Track the below URL for one-step submission https://juniperpublishers.com/online-submission.php 